\title{
Overview of the charts representing eastern coast of the Adriatic Sea through centuries and a comparison of Piri Reis symbology usage with an INT 1 content
}

\author{
Ivana Racetin ${ }^{\mathrm{a}, *}$, Majda Ivić ${ }^{\mathrm{a}}$, Jelena Kilić ${ }^{\mathrm{a}}$, Katarina Rogulj ${ }^{\text {a }}$ \\ ${ }^{a}$ University of Split, Faculty of Civil Engineering, Architecture and Geodesy, ivana.racetin@gradst.hr, majda.ivic@gradst.hr, \\ jelena.kilic@gradst.hr, katarina.rogulj@gradst.hr \\ * Corresponding author
}

\begin{abstract}
An overview of the charts of the eastern coast of the Adriatic Sea is given. It was explained the way Adriatic Sea is spreading in accordance to Mediterranean Sea. Its importance throughout history of Europe was emphasised. Through centuries there were different maps of Europe and Mediterranean Sea. Important graphical representation were also charts/portolans which were a strong help in vessels navigation. In classical period peripluses were drawn and used mostly by Greeks for navigation. Two very famous works representing coast of the Adriatic Sea - Geography of Claudius Ptolemy and Tabula Peutingeriana were explained. Most of the paper is dedicated to portolans and their usage for navigation on eastern Adriatic coast. An overview of most important cartographers of portolans was given. In detail was described Ottoman cartographer of portolans Piri Reis. His symbology usage was analysed and compared to Symbols and abbreviations used on charts (INT 1) content.
\end{abstract}

Keywords: chart, INT 1, Piri Reis, portolans, topographic content

\section{Introduction}

The shores of the oceans and seas today are one of the most populated areas on Earth. According to United Nations (2017) the ocean is vast, covering 363 million square $\mathrm{km}$, equivalent to approximately $72 \%$ of the earth's surface. More than 600 million people (around $10 \%$ of the world's population) live in coastal areas that are less than $10 \mathrm{~m}$ above sea level. Nearly 2.4 billion people (about $40 \%$ of the world's population) live within $100 \mathrm{~km}$ of the coast. Oceans, coastal and marine resources are very important for people living in coastal communities, who represent $37 \%$ of the global population in 2017.

Going ashore has been a centuries-old aspiration of many nations and the goal of many migrations throughout history. But it didn't stop there. After some nations went ashore, the next aspiration was to build ships, get to the coastal islands, fish and learn how to conquer the sea and put it in the service of people.

In order to conquer oceans and seas, shipbuilding knowledge was needed. Nations then needed to learn about navigation, latitude, wind directions on the fairway and it was necessary to produce devices for orientation such as compass and others.

The experience of sailors and the shape of coasts and islands were to be preserved as a permanent record for future generations. Charts, along with ships, were the greatest value of survival at sea. What was valid for the world, was also valid for Europe, and thus for the Adriatic Sea and its eastern coast.

\section{The Adriatic Sea}

The Adriatic Sea is a part of the Mediterranean basin. It spreads between the Balkan and Apennine Peninsula, and extends to the Straits of Otranto in the southeast. Its length is $783 \mathrm{~km}$, average width is $248.3 \mathrm{~km}$, and average depth is $173 \mathrm{~m}$. It covers $138,595 \mathrm{~km}^{2}$.

The islands are spread mostly along the eastern Adriatic coast. 718 islands and islets can be found there. The eastern coast, except Istria, stretches from northwest to southeast and coincides with the tectonic, geological and orographic direction of the mainland.

The east coast is characterized by numerous bays, coves and ravines, by which such a coast is considered a Dalmatian type of coast.

The length of the coastal line of the entire Adriatic Sea is $3690 \mathrm{~km}$, and the coastal line of the islands is $4164 \mathrm{~km}$ long (Ravlić, 2021).

\section{The eastern coast of the Adriatic Sea on maps until the Portolan Epoch}

According to Kozličić (2005) the mapping of the eastern coast of the Adriatic Sea is an integral part of the history of mapping of the Mediterranean and Europe. It was the shortest, easiest and cheapest corridor connecting Europe with Asia and Africa throughout history. For thousands of years, most of shipped cargo was transported on vessels along the east coast of the Adriatic Sea. That is the reason why it was well known coast in classical period.

In that period for sailing were used so called peripluses (Greek $\pi \varepsilon \rho i ́ \pi \lambda o v \varsigma:$ sailing). It was the name for a voyage 
along the coast and a description of that voyage characteristic of the period of Phoenician and Greek colonization of the Mediterranean Sea. The peripluses contained a textual description of coasts and ports and data on the distances (in stages) between individual places on the coast, and on the depths and shallows. The oldest periplus (ca. $450 \mathrm{BC}$ ) is attributed to Hanoch of Carthage. It describes sailing along the west coast of Africa. The Greek periplus from $355 \mathrm{BC}$ by an unknown author is significant for the Adriatic Sea. It is attributed to Pseudoskilak, and contained textual data on the eastern coast of the Adriatic Sea (Ravlić, 2021).

In the classical period, two capital cartographic works were created depicting, among others, the eastern shores of the Adriatic Sea: Geography of Claudius Ptolemy (second half of the 2nd century) and Tabula Peutingeriana (late 3rd and early 4th century) by an unknown author. Both works show the coast and islands of the Adriatic Sea.

While Ptolemy, for that time, gave a positional good cartographic representation, rich in information, the Tabula Peutingeriana had a completely different purpose. The tabula was, in fact, a cartographic travel handbook. The shape and position of the east coast in relation to the Earth were not that important to its creator. It showed a network of roads in the Roman Empire, whether the traveller was traveling by land or sea. It offered a lot of information for travellers, such as the distance between two places on the east coast, the names of individual places, etc.

The notable Arab cartographer Muhamed el Idrisi also describes the coast of the Adriatic Sea in detail in his works Tabula rotunda (1154) and Tabula itineraria Edrisiana (1161) (Kozličić, 2005).

\section{The eastern coast of the Adriatic Sea on portolans}

Portolan is a handwritten nautical chart drawn on parchment or leather. Portolans evolved from ancient peripluses. They were in use from the 14th to the 17 th century. Nautical charts were often bound in a book (Portuguese atlas). In addition to the cartographic presentation, they contained information on the ports and shores, as well as detailed information on sailing routes and sometimes an astronomical and astrological calendar, and tables of lunar changes. Due to a series of drawn compass roses, they are also called compass maps. They are sometimes in Latin language or in the language of the place of issue. Initially they were without compass roses, and later they had 8,16 or 32 of them (the main one in the middle of the map) connected to each other by loxodrome.

The main centres of maritime cartography in the Portolans Epoch were Venice, Genoa, Marseille and the Balearics. Therefore, it is not surprising that the Adriatic Sea appears on most famous portolans. The oldest preserved portolan is The Pisa chart (Carta Pisana) by an unknown author which dates from the 13th century. The oldest portolan of the famous author, the cartographer from Genoa Pietro Vesconte, dates from the year 1311 and depicts the eastern Mediterranean (Ravlić, 2021). As a pioneer of the portolans field, he influenced Italian and Catalan chart making throughout the 14th and 15th centuries. He appears to have been the first professional chart maker to sign and date his works regularly (URL 1). The oldest Portuguese chart of the Adriatic Sea dates from the beginning of the 14th century. It is a small chart included in the atlas Tammaro Luxoro, which shows 43 ports on the east coast of the Adriatic Sea. The map of Vesconte from 1318 shows 58 ports of the eastern Adriatic (Marković 1993).

Some of the prominent authors of portolans depicting the eastern coast of the Adriatic Sea are: Battista Agnese, Gratiosus Benincasa, Pietro Coppo (Petar Kopić), Vicko Dimitrije Volčić Dubrovčanin, etc. To date, hundreds of portolans have been found, including the eastern Adriatic coast portolans.

Gratiosus Benincasa was the most famous author of 15 th century portolans. In his time he produced about one hundred of portolans. His portolan of the Adriatic Sea, made in 1472 is one of the largest ever made. It gives the most faithful view of Istria until his time. The Šibenik Bay and the Pelješac Peninsula are also well presented. That chart was a major step in the depiction of the eastern Adriatic coast (Marković 1993).

The characteristic of portolans is that they were constantly checked in practice, supplemented and improved. That made them better, and it made their content more accurate and richer with information.

Volčić's portolans are one of the last portolans drawn by hand made with brush on parchment. He was quite traditional in his approach to cartography. He used the technique of drawing with brush on parchment, more than a hundred years after the invention of printing. He followed the drawings of famous schools in Palma de Mallorca, Genoa, Venice and Ancona. Volčić was especially influenced by the cartographers of the portolan workshop in Ancona (Italy), primarily by Gratiosus Benincasa. The portolans of the Turkish navigator and cartographer Piri Reis had an indirect influence on Volčić's work (Novak, 2005).

It is characteristic of Volčić's portolans that they are decorated with colours, figures and compass roses. The names of ports and harbours of special importance are marked in red (Lapaine and Kljajić, 2009).

According to Marković (1993), the way of presenting all portolans is similar in its content of depictions at sea. The coastline was drawn by means of a thin black line in the form of smaller arches, concave towards the mainland, and convex towards the open sea. The names of the ports are always written in black, as are the course lines. For the other cartographic data green, blue, red, silver, and gold were often used.

From the previous two sections, we can see that Volčić has moved away from the usual way of presenting content of portolans. The Ottoman cartographer Piri Reis was especially famous for improving the portolans 
content. In the following, we will analyse the content of some of his large-scale portolans showing parts of the eastern Adriatic coast.

\section{Portolans of the eastern Adriatic Sea coast made by the Ottoman cartographer Piri Reis}

\subsection{Piri Reis and Kitab-i Bahriye}

Piri Reis, by the full name Haji Muhjiddin Piri (Gelibol, c. 1465-70 - 1554) was a pirate, sailor, admiral and cartographer. His most significant works are the famous map of the world from 1513, the map of the world from $1528 / 29$, and the book Kitab-i Bahriye - Book of Navigation, instructions for sailors. The first manuscript version of the book was consolidated in 1521, and its second manuscript, revised and expanded edition (210 instead of 130 chapters and maps), was completed in 1526. The book was considered the largest geographical and Ottoman collection of the time, and there are numerous copies of it around the world.

Each chapter of the book is dedicated to a particular region and accompanied by a chart. Compared to the first version of the book, most changes were experienced by depictions of the Adriatic Sea and the west coast of Italy. In the second volume, of the second version of the book, with the subtitle Dalmacya kiliyari, 23 maps of the east Adriatic coast and islands were published.

The volume contains charts of the cities: Dubrovnik and its surroundings, Šibenik, Zadar, Medulin, Pula, Rovinj, Vrsar, Poreč, Novigrad and Umag. There are also charts of the islands: Mljet, Korčula, Vis, Hvar, Molat, Skarda, Rab, Premuda, Pag, Krk, Cres, Unije and Verdura. These portolans are among the oldest cartographic documents of Ottoman origin, which show the eastern coast of the Adriatic in a larger scale (Lapaine and Kljajić, 2009).

5.2 Analysis of the symbology content of some charts from Dalmacya kiliyari by its comparison to INT 1 symbology

Many authors analysed Piri Reis charts. For instance Akcura (1966) describes the content of Piri Reis's portolans as: fortifications and the cities are drown in red, while the uninhabited regions are black. The rocks are indicated as dots, shallow waters and beaches with red dots, while the submarine reefs are marked with small crosses.

Soucek (1987) wrote in details about life of Piri Reis in the book by edithors Harley and Woodward The History of Cartography, Volume 2, Book 1. He analysed his Kitab-i Bahriye - Book of Navigation also explaining content of some of his Adriatic islands portolans.

Novak et al. (2005) made a study comparing Ottoman mapping of the Croatian coast and islands in the 16th century. They analyse Piri Reis charts on six different edition of Kitab-i Bahriya. The study analyses the Croatian part of the eastern Adriatic coast from Dubrovnik to Umag on the Istrian peninsula. Methods of general and special visual comparison of charts were used.
Using the same visual method, and analysing three reproductions of charts published in the paper of Novak and Mlinarić (2005), we were guided by a comparison of the symbology content with a symbology content on modern nautical charts. The charts we analysed were Piri Reis's chart of Dubrovnik (Figure 1), chart of Mljet (Figure 2) and chart of Korčula (Figure 3).

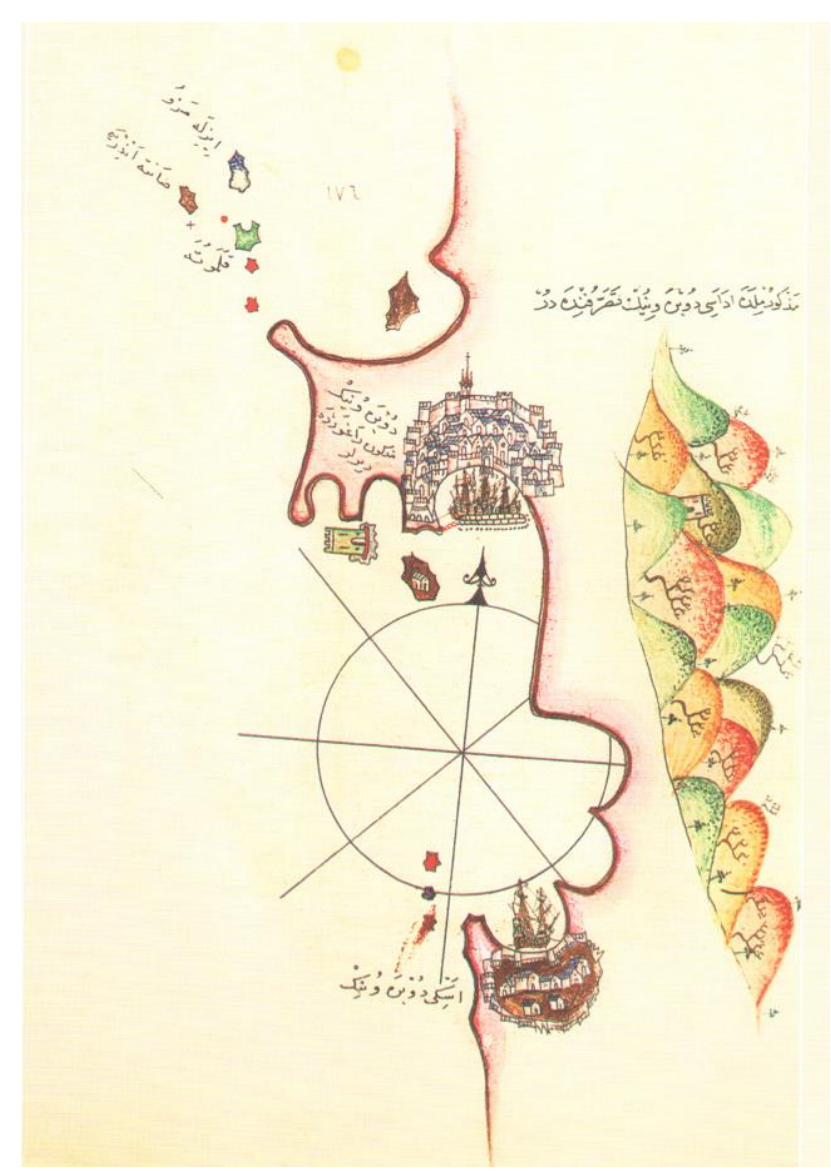

Figure 1. Piri Reis, DUBROVNIK, Raguza Nova, Raguza Vane and ESKI DUBROVNIK, map of Dubrovnik and the Surrounding Area from Kitab-i Bahriye II/1. Facsimile: The Novak Collection (Novak and Mlinarić, 2005) 


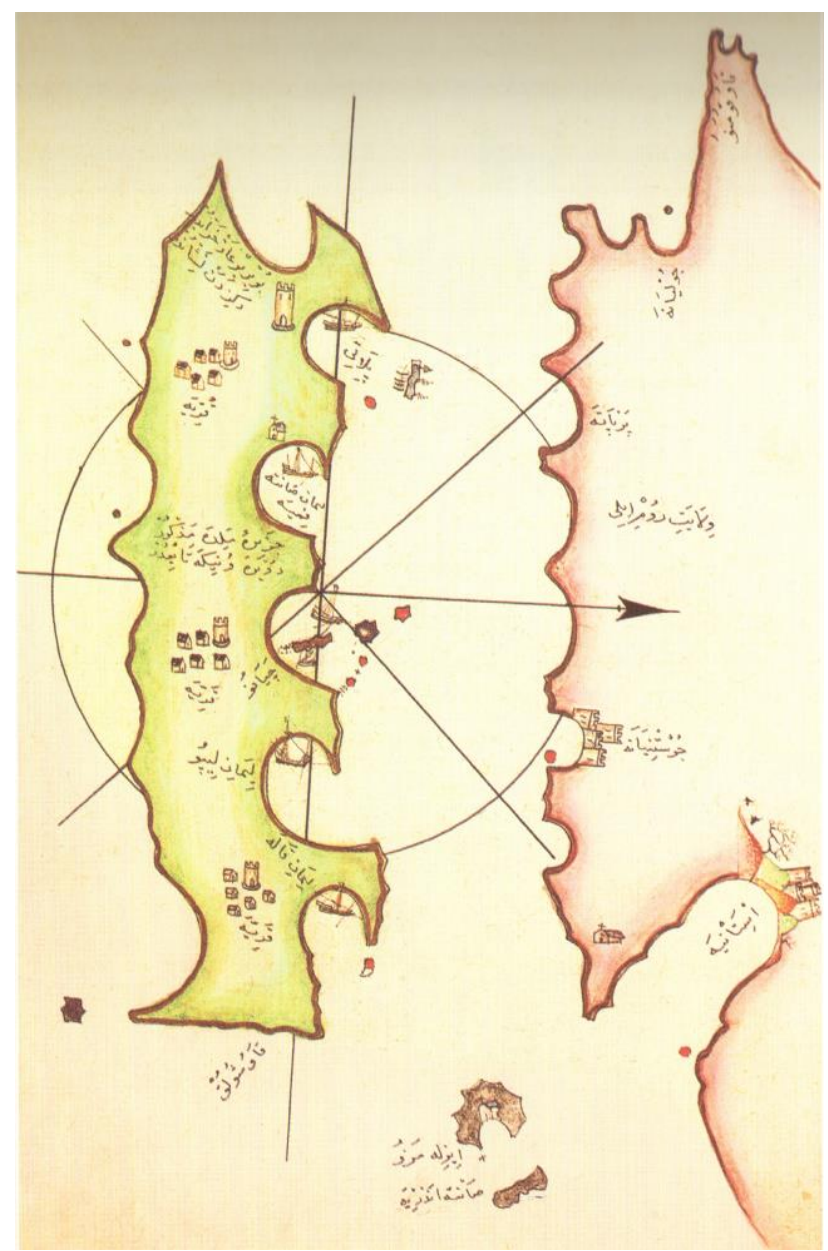

Figure 2. Piri Reis, Isolario of Mljet (MELIDE ADASI). Facsimile: The Novak Collection (Novak and Mlinarić, 2005)

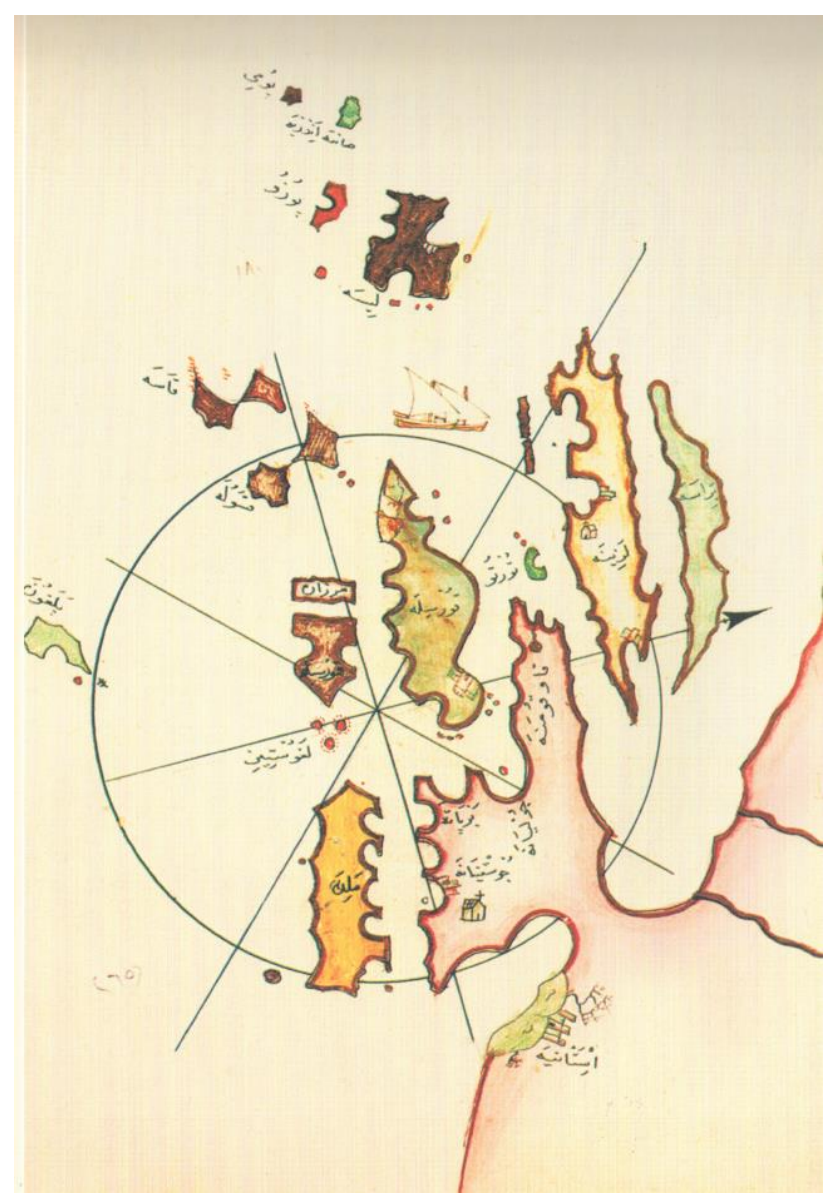

Figure 3. Piri Reis, Isolario of Korčula (KORSILE), map of Pelješac peninsula. Facsimile: The Novak Collection (Novak and Mlinarić, 2005)

We compared the symbology content of the three Piri Reis portolans with a modern cartographic symbols in Symbols and abbreviations used on charts (INT 1) (Gržetić, 2013) (Figure 4).

In the year 2013 the sixth edition of INT 1 Symbols and Abbreviations used on Charts was published by the Hydrographic Institute of the Republic of Croatia (HHI) and it is the latest edition of the INT 1 published in Croatia. It is based upon the Chart Specifications of the International Hydrographic Organization (IHO) which came into force at the XIIth International Hydrographic Conference in 1982 in Monaco.

INT 1 contains the complete symbols, abbreviations and terms used on international as well as national (Croatian) paper charts of the Hydrographic Institute of the Republic of Croatia (HHI).

Observing the cartographic symbols for nautical charts in INT 1 (Gržetić, 2013) we found that they are divided into four basic groups: General, Topography, Hydrography and Navigation Aids and Services (Figure 5).

The first group General is divided into subgroups: Chart Number, Title and Marginal Notes, Positions Distances, Directions and Compass.

Second group Topography is divided into subgroups: Natural Features, Cultural Features (Figure 6), 
Landmarks and Ports.

Third part Hydrography consists of the subgroups: Tides and Currents, Depths, Nature of the Seabed, Rocks, Wrecks and Obstructions, Offshore Installations, Tracks and Routes, Areas and Limits.

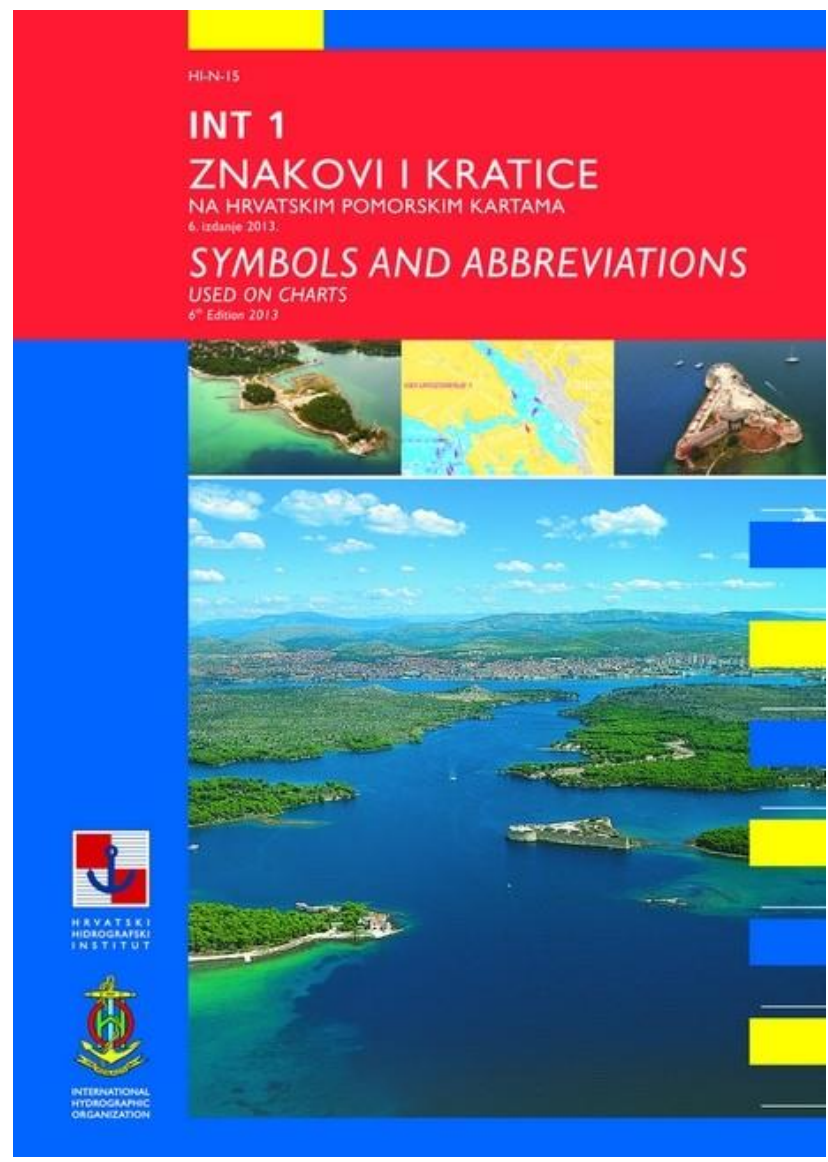

Figure 4. Symbols and abbreviations used on charts (INT 1) (Gržetić, 2013)
SADRŽAJ

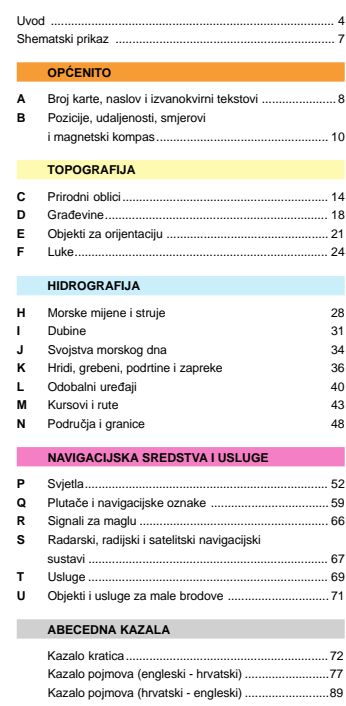

CONTENTS

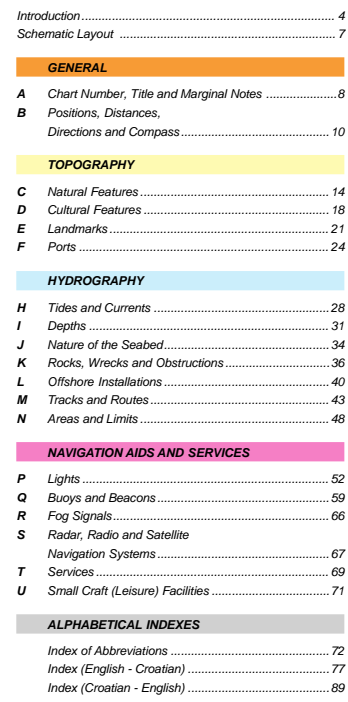

Figure 5. INT 1 content (Gržetić, 2013)

D Građevine
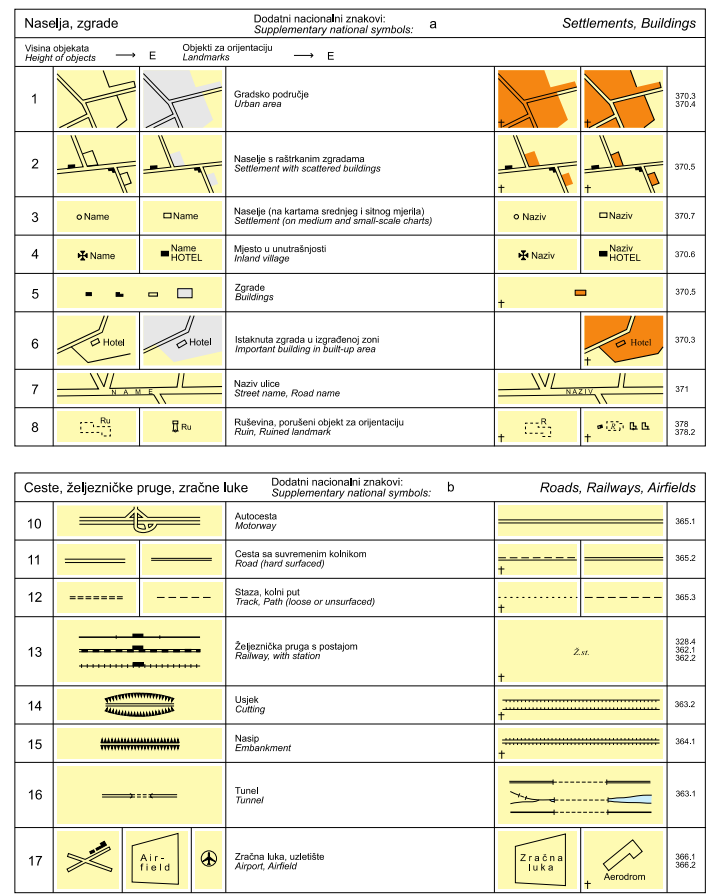

Figure 6. Symbology example in INT 1 in Croatian and English language (Gržetić, 2013)

We didn't compare the data from group Navigation Aids and Services since there are no data on Piri Reis charts to 
compare with.

We established that on the three analysed Piri Reis portolans can be found the same content as in the INT 1 Topography group and that is relief (hills), settlement (city), church, tower, coast and islands (coastline), vegetation (deciduous and coniferous forest), tower, individual houses, fortresses and harbours.

Relief still exists on modern charts. It is defined in INT 1 Topography subgroup Natural Features. Symbols for coastline and vegetation (wood) are in the same subgroup.

In the subgroup Cultural Features there are symbols for urban areas and settlement with scattered buildings and a single building. Also, there are symbols for ruin, ruined landmark and important building which could be equivalent to an observatory on Piri Reis portolans.

In the subgroup Landmarks there is a symbol of church, tower, fortified structure, castle and fort.

In the subgroup Ports there are symbols related to ports as equivalent to ports on Piri Reis portolans.

Hydrography data on three analysed Piri Reis portolans are: anchorage, rocks, shallow waters and beaches and the submarine reefs. Tides and currents were explained in textual and not graphical part, so there is no graphical symbols of them on Piri Reis portolans and we can't do the graphical comparison. The same could be concluded for depths. The nature of the seabed was also not on Piri Reis portolans of that time.

Probably the most important Piri Reis symbols are content of a INT 1 subgroup Rocks, Wrecks and Obstructions. Piri Reis placed great emphasis on those type of symbols. On his portolans were emphasised symbols for rocks, shallow waters and beaches and submarine reefs.

The fact that this subgroup in INT 1 is included with as many as 37 different characters speaks for itself.

We can conclude that the INT 1 part Rocks, Wrecks and Obstructions was rather strongly developed since the time of Piri Reis and it is extremely important for the safety of navigation at sea.

Part Tracks and Routes was not on Piri Reis portolans, but explained in textual part.

The last symbol from three Piri Reis portolans is the one for anchorage which is in subgroup Areas and Limits of the INT 1 chart.

It is interesting that INT 1 does not have a symbol for north, since all modern charts are oriented in a northerly direction, that is not the case with Piri Reis portolans.

It must be added that Piri Reis portolans have a huge number of toponyms as does the charts of today.

\section{Conclusions}

Today, the seas and oceans are the subject of the most of the world's trade. In the last one hundred years, we witnessed a great expansion of coastal tourism, due to great climate conditions favoured by the combination of sea and land. It should be noted that the seas and oceans are also an important source of food.

All that happened due to the first enthusiasts, cartographers who, skilfully produced portolans among others types of charts. In that group there are numerous cartographers of the Italian, Spanish and Ottoman schools. One of them is Piri Reis, who presented the eastern Adriatic Sea coast as it looked like in his time.

The research presents that the portolans were rich in data available to cartographers in that time. The vast majority of the data they draw on charts/portolans were those from the sources available to them. In those days cartographers were oriented on land and sea and data for ships and safety of navigation.

It is fascinating that modern nautical charts do not deviate significantly from the charts of that time by selecting the objects to display.

With the development of navigation and maritime affairs, there has been a significant increase in the construction/installation of facilities on the coast and at the sea, which increased safety in modern navigation.

The difference in symbols representation in 16th century charts/portolans and modern charts is mostly expressed through that segment of new built objects at sea, for e.g. lights, buoys and beacons, fog signals etc.

It could be concluded that the approach to creating charts/portolans in case of Piri Reis and in case of modern charts (if we neglect positional accuracy) is not so different in sense of approaching to chart generalization.

\section{References}

Akcura, Y. (1966). Piri Reis map, Istanbul.

Gržetić, Z. (2013). Symbols and abbreviations used on charts (INT 1), Hydrographic Institute of the Republic of Croatia, Split.

Kozličić, M. (2005). Historical Development of the Mapping of Croatian Lands, Five Centuries of Maps and Charts of Croatia, ed. Novak, D., Lapaine M., Mlinarić, D., Školska knjiga, Zagreb

Lapaine, M., Kljajić, I. (2009). Hrvatski kartografi, biografski leksikon, Goldeng marketing-Tehnička knjiga, Zagreb.

Marković, M. (1993). Descriptio Croatiae, Hrvatske zemlje na geografskim kartama od najstarijih vremena do pojave prvih topografskih karata, Naprijed, Zagreb.

Novak, D (2005). Vicentius Demetrius Volcius Raguseus (1563-1607), A Portolan Chart Maker from Dubrovnik, Five Centuries of Maps and Charts of Croatia, ed. Novak, D., Lapaine M., Mlinarić, D., Školska knjiga, Zagreb.

Novak, D., Mlinarić, D. (2005). Adriatic Coast and Islands in the Kitab-i Bahrye by Piri Reis, Five Centuries of Maps and Charts of Croatia, ed. Novak, D., Lapaine M., Mlinarić, D., Školska knjiga, Zagreb.

Novak, D., Mlinarić, D., Lapaine, M. (2005). A Comparative Analysis of the 16th Century Ottoman 
Mapping of the Croatian Coast and Islands, Kartography and Geoinformation, vol. 4, 78-110.

Ravlić, S. (2021). Hrvatska enciklopedija, Leksikografski zavod Miroslav Krleža, Zagreb. https://enciklopedija.hr/ (3.03.2021.)

Soucek, S. (1987). Islamic Charting in the Mediterranean, The History of Cartography, Volume 2 Book 1, ed. Harley, J. B., Woodward, D., The University of Chicago Press, Chicago.

United Nations (2017). Ocean fact sheet package, The Ocean Conference, 5-9 June 2017, New York, 1-7. www.un.org/sustainabledevelopment/wpcontent/uploads/2017/05/Ocean-fact-sheet-package.pdf (1.03.2021.)

URL 1 Wikipedia, Pietro Vesconte https://en.wikipedia.org/wiki/Pietro_Vesconte $(5.03 .2021)$ 